\title{
AN INVESTIGATION ON ACADEMIC ACHIEVEMENT AND LEARNING STYLES AS TO BRANCHES AND GENDER FROM FACULTY OF EDUCATION STUDENTS,
}

\author{
Hüseyin Hüsnü BAHAR * $\quad$ Yener ÖZEN** \\ Fikret GÜLAÇTI***
}

\begin{abstract}
This study aimed to determine students' preferred learning styles, academic achievement and to investigate whether there was a significant difference in students' preferred learning style and academic achievement level according to their program and gender. This study involved in 433 students from Erzincan Faculty of Education in the 2006-2007 academic year. Turkish version of Kolb Learning Style Inventory (LSI) was used to collect the data about student's learning style. The data about students' academic achievement were collected from Faculty records. The data that was obtained from LSI and Faculty records was analyzed using by t-test, ANOVA and chi-square techniques. The results show that academic achievement of female students was significantly higher than male students' and learning style do not differ significantly in relation to the gender. In addition, the level of academic achievement and learning style was found significantly different according to the enrolling teacher education program. The other findings showed that $43.6 \%$ of the students were converger, $29.3 \%$ of students were assimilator, 16.3 $\%$ of the students were accommodator, and $10.8 \%$ of the students were diverger. There was not any difference between students' grade point average as to learning style.
\end{abstract}

Key Words: Learning style, academic achievement, faculty of education

\footnotetext{
* Assist. Prof. Dr., Erzincan University, Faculty of Education e-posta: hhbahar@hotmail.com

*** Res. Assist., Erzincan University, Faculty of Education e-posta: yozen24@hotmail.com

**** Res. Assist., Erzincan University, Faculty of Education e-posta: fikretgul@hotmail.com
} 


\section{Purpose and significance:}

\section{SUMMARY}

There are a lot of variable that affect on students' level of academic achievement. Generally, these variables which connect with physiological, psychological and social condition are known as "learning variables". At the same time, one of the learning variables is the learning style. The arrangement of teaching and learning environment point of learning style is important as to reach to the educational aims. This study aimed to determine students' preferred learning styles, academic achievement and to investigate whether there was a significant difference in students' preferred learning style and academic achievement level according to their program and gender. This study involved in 433 students from Erzincan Faculty of Education in the 2006-2007 academic year.

\section{Method:}

In the Kolb's Learning Model, learning style of the person is a circular form. Using Learning Style Inventory (LSI), place of person in this circle is determined. There are four individual learning styles for this circle: concrete experience (CE); reflective observation (RO); abstract conceptualization (AC) and active experimentation (AE). Learning strategies to clear the learning styles are different from each other. There are four learning modes: options relating to 'feeling' for concrete experience; 'watching' for reflective observation; 'thinking' for abstract conceptualization; 'doing' for active experimentation. However, there is not one learning mode for each person, but there are different learning modes. Learning style for each person is component of these four modes. These learning styles are convergers, assimilators, accommodators and divergers. These four different learning styles clear person's dominated learning style. Turkish version of Kolb Learning Style Inventory (LSI) was used to collect the data about student's learning style. The reliability coefficients for sub-scales were found to be between .69 and .76 that indicates high reliability of the scale. The data about students' academic achievement were collected from Faculty records. The data that was obtained from LSI and Faculty records was analyzed using by t-test, ANOVA and chi-square techniques. According to result of ANOVA, LSD test was used to find the source of the difference.

\section{Results:}

The results show that academic achievement of female students was significantly higher than male students' and learning style does not differ significantly in relation to the gender. In addition, the level of academic achievement and learning style was found significantly different according to the enrolling teacher education program. The other findings showed that $43.6 \%$ of the students were converger, $29.3 \%$ of students were assimilator, $16.3 \%$ of the students were accommodator, and $10.8 \%$ of the students were diverger. There was not any difference between students' academic achievement as to learning style.

\section{Discussion and Conclusions:}

There are some similar results related to female students are more successful than male students in college education. Different teacher education programs needs to different activities and skills. For this reason, it is expected result to find academic achievement and learning style was found significantly different as to branches. There are some similar and different research findings about that. Perhaps the most interesting finding is that an academic achievement is not different as to learning styles. Future research should focus on this subject. In addition, some other research should focus on the relationship between sex and academic achievement. 


\title{
EĞITTIM FAKÜLTESI ÖĞRENCILERININ CINSIYYET VE BRANŞA GÖRE AKADEMIKK BAŞARI DURUMLARI İLE ÖĞRENME STILLERININ INCELENMESİ ${ }^{1}$
}

\author{
Hüseyin Hüsnü BAHAR * $\quad$ Yener ÖZEN ${ }^{* *}$ \\ Fikret GÜLAÇTI***
}

\begin{abstract}
Öz
Araştırmanın amacı eğitim fakültesi öğrencilerinin cinsiyet ve kayitlı olunan programa göre öğrenme stillerini tespit etmek, akademik başarı durumlarının öğrenme stillerine göre değişip değişmediğini belirlemektir.

Araştırmaya 2006-2007 Akademik Yılında Erzincan Eğitim Fakültesine kayıtlı 443 öğrenci katılmıştır. Veri toplama aracı olarak Kolb Öğrenme Stili Envanteri kullanılmış, öğrencilerin akademik başarı puanları fakülte kayıtlarından elde edilmiştir. Veri analiz sürecinde bağımsız örnek t-testi, tek yönlü varyans analizi ve ki kare testi kullanılmıştır. Yapılan analizler sonucunda, kız öğrencilerin akademik başarı ortalaması erkek öğrencilerin akademik başarı ortalamalarından daha yüksek bulunurken, öğrenme stillerinin cinsiyete göre farklı olmadığı bulunmuştur. Öğrencilerin kayıtlı olduğu öğretmen yetiştirme programına göre akademik başarıları arasındaki fark anlamlı bulunmuş ve kayıtlı olunan programa göre öğrenme stillerinin farklı olduğu tespit edilmiştir. Öğrencilerin en çok ayrıştıran (\% 43.6), ikinci olarak özümseyen (\% 29.3) öğrenme stilini tercih ettikleri, yerleştiren (\% 16.3) ve değiştiren (\% 10.8) öğrenme stilini tercih etme oranının daha düşük olduğu bulunmuştur. Yerleştiren, değiştiren, ayrıştıran ve özümseyen öğrenme stiline sahip öğrencilerin ağırlıklı not ortalamaları arasındaki farkın anlamlı olmadığı bulunmuştur.

Anahtar Kelimeler: Öğrenme stili, akademik başarı, eğitim fakültesi
\end{abstract}

\footnotetext{
${ }^{1}$ Bu çalışma 16'ncı Eğitim Bilimleri Kongresinde bildiri olarak sunulmuştur.

"Yrd. Doç. Dr., Erzincan Ü., Eğ. Fak., Eğitim Bil. Bölümü, e-posta: hhbahar @ hotmail .com ** Araş. Gör., Erzincan Ü., Eğitim Fak., İlköğretim Bölümü, e-posta: yozen24@ hotmail.com

****A Araş. Gör., Erzincan Ü., Eğitim Fak., İlköğretim Bölümü, e-posta: fikretgul@hotmail.com
} 


\section{GİRIŞ}

Akademik başarı, okul ortamında öğrencinin akademik etkinliklerden ne ölçüde yararlandığının bir göstergesi olarak değerlendirilebilir (Özgüven 1998). Ancak, bu başarı okuldaki eğitim-öğretim faaliyetlerinin niteliğinden etkilendiği gibi, okul dışı çeşitli faktörlerden de etkilenmektedir (Celkan 1983). Öğrencinin akademik başarı seviyesinde etkili olan pek çok değişken bulunmaktadır. Genellikle fizyolojik, psikolojik, toplumsal durum ve koşullarla ilgili olan bu değişkenler "öğrenme değişkeni" olarak da adlandırılır. Öğrenme değişkenleri, öğrencinin öğrenme durumunu, dolayısıyla başarı düzeyini olumlu ya da olumsuz olarak etkiler (Uluğ 1996). Öğrenme durumunu etkileyen faktörlerden birisi de öğrenme stilidir.

Öğrenme sürecinde her insanın öncelik verdiği birtakım yol ve yöntemler bulunmaktadır. Bu öncelikler kişiden kişiye değişiklik gösterir ve bireyin öğrenme stilini ortaya koyar. Bazı araştırmacılara göre (Dunn, Beudury ve Klavas 1989), ögrenme stili bireyin imzası gibi olup, bilinmesi yöntem seçimine ve ortam düzenlenmesine katkı sağlar.

Yöntem ile teknik arasındaki ilişki örüntüsü, strateji ve taktik arasında bulunmaktadır. Strateji, yöntemin üzerinde daha geniş bir şemsiye oluşturmaktadır. Strateji; yöntemi kapsamakla birlikte alınacak önlemleri de içinde barındırır. $\mathrm{Bu}$ bağlamda strateji ve taktikler, öğreticiye yöntem ve tekniklere göre daha geniş bir hareket alanı çizer. Stil ise bu iki kavramsal yapıyı yönlendiren, bireysel özellikler takımı olarak ortaya çıkmaktadır (Babadoğan 2000).

Öğrenme stillerinin doğası ve belirleme yöntemleri konusunda farklı yaklaşımlar vardır. Bunun temel nedeni, bireyin öğrenme stilinin bilişsel, duyuşsal ve fizyolojik olmak üzere üç farklı boyutunun olması ve kuramcıların bunlardan birisi üzerinde odaklanmasıdır (Ekici 2003). Hem bilişsel hem de duyuşsal boyutlar üzerinde odaklanan Kolb Öğrenme Stili (Kılıç 2002), bireyin bilgiyi algılama ve işlemesinde kişisel olarak tercih ettiği yönteme önem verir.

Kolb Öğrenme Stili modelinin temelini Kolb’un Yaşantısal Öğrenme Kuramı (Experiental Learning Theory) oluşturmaktadır. Diğer bilişsel öğrenme teorilerinden farklı olarak yaşantısal öğrenme, öğrenme sürecinde deneyimlerin rolünü vurgulamaktadır (Kaf Hasırc1 2006).

Kolb'un öğrenme modelinde bireylerin öğrenme stilleri bir döngü şeklindedir. Öğrenme Stili Envanteri (ÖSE) ile bireylerin bu döngünün neresinde yer aldığı belirlenir. $\mathrm{Bu}$ döngü içinde dört öğrenme biçimi bulunmaktadır. Bunlar Somut Yaşantı (SY), Yansıtıcı Gözlem (YG), Soyut Kavramsallaştırma (SK) ve Aktif Yaşantı (AY)'dır. Öğrenme biçimini temsil eden öğrenme yolları birbirinden farklıdır. Bunlar, Somut yaşantı için "Hissederek", Yansıtıcı Gözlem için "İzleyerek", Soyut Kavramsallaştırma için "Düşünerek", Aktif Yaşantı için "Yaparak" öğrenmedir. Ancak, bireyin 
öğrenme stilini belirleyen tek bir biçim bulunmamaktadır. Her bir bireyin öğrenme stili bu dört temel biçimin bileşenidir. $\mathrm{Bu}$ nedenle, bir öğrenme durumu içerisine çeşitli durumlar bir araya getirilerek yerleştirilmiştir. Bireylerin puanlarının toplamı ile bireylerin en uygun hangi öğrenme stiline girdiği belirlenir. $\mathrm{Bu}$ öğrenme stilleri "Yerleştiren", “Özümseyen", "Değiştiren" ve "Ayrıştıran"dır. Bu dört farklı öğrenme stili bireyin hem baskın öğrenme stilini hem de öğrenme tercihlerini ortaya çıkarır (Aşkar ve Akkoyunlu 1993).

Öğretimde amaç öğrenmenin gerçekleşmesidir. Bunun en verimli biçimde gerçekleşmesi, diğer bir deyimle, en az emek harcanarak, asgari maliyetle azami öğrenmenin sağlanması istenir. Bunu sağlamanın birçok koşulu vardır. Bunlardan birisi de öğrencinin öğrenme stiline uygun öğrenme ortamı hazırlamaktır. Öğrencilerin öğrenme stillerini bilmek, uygun öğrenme ortamı oluşturmak bakımından önemlidir. Farklı öğrenme stillerine uygun öğrenme ortamlarının oluşturulması öğrenmeyi kolaylaştırır.

Öğretme-öğrenme sürecinin öğrenme biçimlerinin dikkate alınarak düzenlenmesinin eğitsel amaçlara ulaşılması açısından oldukça önemli olduğu, öğretme-öğrenme sürecinin etkililiğinin öğrenenin öğrenme gereksinimini karşılamasına ve öğrenme biçemine göre düzenlenmesine bağlı olduğu göz ardı edilmemelidir (Boydak 2001, Mahiroğlu 1999).

Kendi öğretim stili ne olursa olsun, öğreticinin sinıfinda bulunan dört farklı öğrenme stiline sahip öğrenen grubuna, onların gereksinimlerini karşılayıcı biçimde eşit davranması gereklidir. Sınıf içindeki bazı öğrenenler otorite kaynaklı öğrenmeye yatkın iken, bir başka grup öğrenen ise tartışma yoluyla öğrenmeyi tercih edebilir. Öğretici çoğu zaman kendi öğrenme stiline sahip öğrenen grupla karşılaşabilir. Burada öğreticiden beklenen karşıt stil grubundaki öğrenenlerin de gereksinimlerini karşılayabilmesi, bir yerde onların da öğreticisi olabilmesidir (Babadoğan, 2000).

\section{Araştırmanın Amacı}

Araştırmanın amacı eğitim fakültesi öğrencilerinin cinsiyet ve kayıtlı olunan programa göre öğrenme stillerini tespit etmek, akademik başarı durumlarının öğrenme stillerine göre değişip değişmediğini belirlemektir. $\mathrm{Bu}$ amaçla aşağıdaki sorulara cevap aranmıştır:

1. Öğrencilerin öğrenme stillerine göre akademik başarı durumları arasinda fark var midır?

2. Öğrencilerin akademik başarı durumları ve öğrenme stilleri cinsiyete göre değişiklik göstermekte midir?

3. Öğrencilerin akademik başarı durumları ve öğrenme stilleri kayıtlı oldukları öğretmen yetiştirme programına göre değişiklik göstermekte midir? 


\section{Araștırmanın Önemi}

Eğitim - öğretim etkinliklerinin öğrencinin öğrenme stiline uygunluğu akademik başarıyı etkileyebilecek faktörlerden birisidir. Bireyin kendisine en uygun öğrenme stilini bilmesi öğrenme gücünü artırmasına yardım eder (Aşkar ve Akkoyunlu, 1993). Öğrencilerin okul başarısızlıklarını en alt düzeye indirmek, hatta ortadan kaldırmak için çok yönlü araştırmaların yapılması gerekmektedir (Küçükahmet, 1997). Yapılan bu araştırma meslek seçimini yapmış öğretmen adaylarının öğrenme stillerinin öğretmenlik branşına göre değişip değişmediğini tespit etmek bakımından önemlidir. Ayrıca, öğretim sürecindeki uygulamalar bazı öğrenciler için uygun öğrenme koşulları oluştururken öğrenme stili farklı olan öğrenciler için dezavantaj oluşturabilir. Avantaj veya dezavantaj öğrenmenin göstergesi olarak kabul edilen akademik başarı puanlarında rahatlıkla görülebilir. $\mathrm{Bu}$ araştırma, öğrenme stilleri farklı olan öğrencilerin öğrenme düzeylerinin, dolayısıyla akademik başarı durumlarının farklı öğrenme stiline sahip öğrenciler için avantaj veya dezavantaj oluşturup oluşturmadığını tespit etmek bakımından da önemlidir.

Öğrencilerin öğrenme stillerinin belirlenmesi, öğretmenlere öğretim sürecinde nasıl bir yöntem geliştirecekleri konusunda yardımcı olabilir (Akkoyunlu, 1995). Sınıf içi öğrenme-öğretme etkinliklerinin öğrencinin öğrenme stiline uygun olması, öğrencinin öğrenmesini kolaylaştıracak ve akademik başarısının artmasına katkı sağlayacaktır.

\section{YÖNTEM}

\section{Araştırma Modeli}

$\mathrm{Bu}$ araştırma, öğrencilerin cinsiyet ve kayıtlı oldukları öğretmen yetiştirme programına göre akademik başarıları ile öğrenme stillerini incelemek üzere planlanmış betimsel bir çalışmadır.

\section{Evren ve Örneklem}

Araştırma evrenini, Erzincan Üniversitesi Eğitim Fakültesinin 20062007 Akademik Yılında, beş farklı öğretmen yetiştirme programına kayıttı bulunan toplam 1347 öğrenci oluşturmaktadır. Örnekleme yöntemi olarak küme örnekleme yöntemi kullanılmıştır. Erzincan Üniversitesi Eğitim Fakültesinin beş farklı öğretmen yetiştirme programının bir ve dördüncü sınıfına devam eden toplam 443 ögrenci seçkisiz olarak örnekleme alınmıştır. Bir ve dördüncü sınıf öğrencilerinin seçilme sebebi, araştırmaya konu olan öğrenme stillerinin kısa sürede değişen bir özellik olmaması, bu nedenle bir ve dördüncü sınıf öğrencilerinin ara sınıflar olan iki ve üçüncü sınıf öğrencilerini de öğrenme stili bakımından temsil edebileceği varsayımıdır. 
Tablo 1

Öğrencilerin Kayıtlı Oldukları Programa Göre Frekans ve Yüzdeleri

\begin{tabular}{lcccc}
\hline Öğrencinin Kayıtlı Olduğu Program & $\begin{array}{c}\text { Kayıtlı } \\
\text { Toplam }\end{array}$ & Katılan & $\begin{array}{c}\text { Örnekleme } \\
\text { Oranı }\end{array}$ & $\begin{array}{c}\text { Katılan } \\
\text { Yüzde }\end{array}$ \\
\hline Sınıf Öğretmenliği (SÖ) & 494 & 174 & 35,22 & 39,28 \\
Beden Eğitimi ve Spor Öğretmenliği (BE) & 167 & 54 & 32,34 & 12,19 \\
Fen Bilgisi Öğretmenliği (FB) & 268 & 115 & 42,91 & 25,96 \\
Ilköğretim Matematik Öğretmenliği (MÖ) & 205 & 40 & 19,51 & 9,03 \\
Türkçe Öğretmenliği (TÖ) & 213 & 60 & 28,17 & 13,54 \\
Toplam & 1347 & 443 & 32,89 & 100,00 \\
\hline
\end{tabular}

Araştırma evrenini oluşturan öğrenci sayısı ile araştırmaya katılan öğrencilerin kayıtlı oldukları programa göre frekans ve yüzdeleri ile örnekleme oranı ve katılım yüzdesi Tablo 1'de gösterilmiştir. İkinci öğretim öğrencileri, sınıf öğretmenliği programı dışında ikinci öğretim programı bulunmaması sebebi ile çalışma kapsamı dışında tutulmuştur. Katılan öğrencilerin 276'sı (\% 62,3) erkek, 167'si (\% 37,7) kızdır. Araştırmaya Sınıf Öğretmenliği (SÖ), Beden Eğitimi ve Spor Öğretmenliği (BE), Fen Bilgisi Öğretmenliği (FB), Matematik Öğretmenliği (MÖ) ve Türkçe Öğretmenliği (TÖ) programına kayıtlı öğrenciler katılmıştır.

\section{Veri Toplama Araçları}

Öğrencilerin akademik başarı durumları ile ilgili veriler fakülte kayıtlarından elde edilmiştir. Ağırlıklı Not Ortalaması (AGNO) olarak ifade edilen akademik başarı durumu, 2006-2007 Akademik Yılı Bahar dönemi sonu itibarıyla öğrencilerin almış oldukları derslerin ağırlıklı not ortalamalarını ifade etmektedir. Öğrencilerin kayıtlı olduğu Erzincan Eğitim Fakültesinde, akademik başarı puanlarının hesaplanmasına esas olan değerlendirme sürecinde bağıl değerlendirme sistemi kullanılmaktadır.

Öğrenme stillerini tespit etmek için Kolb (1985) tarafindan geliştirilen, Aşkar ve Akkoyunlu (1993) tarafından Türkçeye uyarlanarak geçerlilik, güvenirlik çalışması yapılan Kolb Öğrenme Stili Envanteri kullanılmıştır. Uyarlama çalışmasında veriler, 18-60 yaş arasında değişik yaş ve meslek grubuna mensup 638 erkek ve 801 kadın olmak üzere toplam 1446 yetişkinden elde edilmiştir. Örneklemin ortalama eğitim düzeyi ise iki yıllık ön lisans seviyesi olarak tespit edilmiştir.

Kolb'un öğrenme modelinde bireylerin öğrenme stilleri bir döngü şeklindedir. Öğrenme Stili Envanteri ile bireylerin bu döngünün neresinde yer aldığı belirlenir. Bu döngü içinde dört öğrenme biçimi bulunmaktadır. Bunlar Somut Yaşantı, Yansıtıcı Gözlem, Soyut Kavramsallaştırma ve Aktif Yaşantı'dır. Envanterde Ayrıştıran, Değiştiren, Özümseyen ve Yerleştiren olmak üzere dört farklı öğrenme stili açıklanmıştır. Uygulanan ölçeğin ortalama ve standart sapma değerleri Tablo 2 'de gösterilmiştir. 
Tablo 2

ÖSE Ortalama ve Standart Sapma Değerleri (N: 443)

\begin{tabular}{lcc}
\hline Öğrenme Biçimleri & Ortalama & $\begin{array}{c}\text { Standart } \\
\text { Sapma }\end{array}$ \\
\hline Somut Yaşantı (SY) & 25.31 & 5.56 \\
Yansitıcı Gözlem (YG) & 27.41 & 6.48 \\
Somut Kavramsallaştırma (SK) & 33.89 & 5.99 \\
Aktif Yaşantı (AY) & 33.44 & 6.81 \\
SK-SY & 8.58 & 9.42 \\
AY-YG & 6.02 & 11.24 \\
\hline
\end{tabular}

ÖSE'nin Cronbach Alpha Güvenirlik katsayıları Tablo 3'te gösterilmiştir. Bulunan güvenirlik katsayıları genel olarak orijinal ölçekte (Kolb 1985) bulunan katsayılardan biraz düşük olmakla birlikte, Aşkar ve Akkoyunlu'nun (1993) uyarladığı Türkçe versiyonu için bulduğu katsayılarla benzerlik göstermektedir. Tablo 3 'te belirtilen güvenirlik katsayıları, ölçeğin yeterince güvenilir olduğunu ve amaca uygun olarak kullanılabileceğini göstermektedir (Kalaycı 2006).

Tablo 3

ÖSE ve Bileşenlerinden Elde Edilen Puanların Güvenirlik Katsayıları

\begin{tabular}{lccc}
\hline & \multicolumn{3}{c}{ Cronbach Alpha } \\
\cline { 2 - 4 } $\begin{array}{l}\text { Öğrenme } \\
\text { Biçimleri }\end{array}$ & $\begin{array}{c}\text { Kolb - 1985 } \\
(\mathrm{N}: 268)\end{array}$ & $\begin{array}{c}\text { Aşkar-Akkoyunlu (1993) } \\
(\mathrm{N}: \text { 103) }\end{array}$ & $\begin{array}{c}\text { Mevcut Çalışma } \\
(\mathrm{N}: \text { 443) }\end{array}$ \\
\hline SY & .82 & .58 & .69 \\
YG & .73 & .70 & .76 \\
SK & .83 & .71 & .74 \\
AY & .78 & .65 & .70 \\
SK-SY & .88 & .77 & .73 \\
AY-YG & .81 & .76 & .75 \\
\hline \multicolumn{5}{c}{}
\end{tabular}

ÖSE ve bileşenlerinden elde edilen puanlarla ilgili pearson korelasyon katsayıları Tablo 4'te gösterilmiştir. Dört temel öğrenme stili arasındaki korelasyonların negatif yönde olduğu görülmektedir. Diğer yandan, SK-SY ile SY ve AY-YG ile YG arasındaki yüksek düzeydeki ilişki negatif iken, SK-SY ile SK ve AY-YG ile AY arasındaki yüksek düzeydeki ilişki pozitif yöndedir. ÖSE puanları arasında bulunan bu ilişki katsayıları, orijinal formun bulunan korelasyon katsayıları ile benzerlik göstermektedir (Kolb 1985). Yaşantısal öğrenme kuramına göre SK ile SY ve AY ile YG arasında güçlü bir negatif ilişki varken, SK-SY ile AY-YG arasında bir ilişkinin olmadığ 1 şeklindedir (Aşkar ve Akkoyunlu 1993). 
Tablo 4

ÖSE ve Bileşenlerinden Elde Edilen Puanlarla İlgili Pearson Korelasyon Katsayıları

\begin{tabular}{|c|c|c|c|c|c|c|}
\hline $\begin{array}{l}\text { Öğrenme Stil ve } \\
\text { Bileşenleri }\end{array}$ & SY & YG & SK & AY & $\begin{array}{l}\text { SK- } \\
\text { SY }\end{array}$ & $\begin{array}{l}\text { AY- } \\
\text { YG }\end{array}$ \\
\hline Somut Yaşantı (SY) & $\overline{1}$ & & & & & \\
\hline Yansıtıcı Gözlem (YG) & $-.327(*)$ & 1 & & & & \\
\hline $\begin{array}{l}\text { Somut Kavramsallaştırma } \\
\text { (SK) }\end{array}$ & $-.329(*)$ & $-.257(*)$ & 1 & & & \\
\hline Aktif Yaşantı (AY) & $-.158\left(^{*}\right)$ & $-.431(*)$ & $-.350(*)$ & 1 & & \\
\hline SK-SY & $-.800(*)$ & .030 & $.830(*)$ & $-.129(*)$ & 1 & \\
\hline AY-YG & .093 & $-.837(*)$ & -.064 & $.854\left(^{*}\right)$ & -.095 & 1 \\
\hline
\end{tabular}

\section{Veri Analiz Yöntemleri}

Veriler bilgisayar ortamında SPSS paket programı ile analiz edilmiştir. Öğrencilerin öğrenme stillerinin cinsiyete ve kayıtlı oldukları programa göre farklı olup olmadığını belirlemek için ki kare bağımsızlık testi kullanılmıştır. Ki kare bağımsızlık testi iki veya daha fazla değişken grubu arasında ilişki bulunup bulunmadığını belirlemek için kullanılır. Bu testin uygulanabilmesi için gözlem sonuçlarının sınıflandırılmış veya gruplandırılmış birleşik seriler şeklinde gösterilmesi gerekir (Kalaycı 2006). Öğrencilerin öğrenme stillerine göre akademik başarı puanları arasında fark olup olmadığını bulmak için tek yönlü varyans analizi yapılmış, hangi gruplar arasında anlamlı fark olduğunu tespit etmek için LSD (Least Significant Different) testi kullanılmıştır. Akademik başarı durumunun cinsiyete göre farklı olup olmadığını tespit etmek için bağımsız örnek t-testi uygulanmıştır. Araştırmada anlamlılık düzeyi $\mathrm{p}<.05$ olarak alınmıştır.

\section{BULGULAR}

Araştırmanın amacı doğrultusunda cevabı aranan ilk soru öğrencilerin öğrenme stillerine göre akademik başarı durumları arasında fark olup olmadığıdır. $\mathrm{Bu}$ amaçla ilk olarak öğrencilerin öğrenme stillerine göre akademik başarı durumları ile ilgili ortalama ve standart sapma değerleri tespit edilmiş ve Tablo 5'te gösterilmiştir. Tablo 5'teki sonuçlar öğrencilerin en çok ayrıştıran, ikinci olarak özümseyen öğrenme stilini tercih ettiklerini göstermektedir. Yerleştiren ve değiştiren öğrenme stilini tercih edenlerin sayısının daha az olduğu görülmektedir. 
Tablo 5

Öğrencilerin Öğrenme Stillerine

Göre Akademik Başarı Durumları

\begin{tabular}{lccc}
\hline Öğrenme Stili & $\mathrm{N}$ & AGNO & Standart Sapma \\
\hline Yerleştiren & 72 & 2.65 & 0.65 \\
Değiştiren & 48 & 2.62 & 0.34 \\
Ayrıştıran & 193 & 2.67 & 0.48 \\
Özümseyen & 130 & 2.59 & 0.53 \\
Toplam & 443 & 2.64 & 0.51 \\
\hline
\end{tabular}

Öğrencilerin öğrenme stillerine göre akademik başarı durumları arasında fark olup olmadığını tespit etmek için ANOVA testi yapılmıştır. Test sonuçları Tablo 6' da gösterilmiştir. Öğrenme stiline göre öğrencilerin AGNO'ları arasındaki farkın anlamlı olmadığı bulunmuştur (F: .698, p > .05). Öğrencinin yerleştiren, değiştiren, ayrıştıran ve özümseyen öğrenme stiline sahip olması onun AGNO'sunu etkilememektedir.

Tablo 6

Öğrencilerin Öğrenme Stillerine Göre Akademik Başarı Durumuna

İlişkin ANOVA Testi Sonuçları

\begin{tabular}{lccccc}
\hline & Kareler toplamı & Df & Ortalama kare & F & Anlamlılık \\
\hline Gruplararası & .562 & 3 & .187 & .698 & .554 \\
Gruplar içi & 117.779 & 439 & .268 & & \\
Toplam & 118.341 & 442 & & & \\
\hline \multicolumn{5}{c}{$\mathrm{p}>.05$}
\end{tabular}

Öğrencilerin akademik başarı durumlarının cinsiyete göre farklı olup olmadığına ilişkin bağımsız örnek t-testi sonuçları Tablo 7'de gösterilmiştir. Test sonuçları öğrencilerin cinsiyete göre akademik başarı ortalamaları arasındaki farkın anlamlı olduğunu göstermektedir (t: -4.364, $\mathrm{p}<.01)$. Erkek öğrencilerin Ağırlıklı Not Ortalaması (AGNO) 2.55 iken kız öğrencilerin AGNO'su 2.78 olarak bulunmuştur. 
Tablo 7

Öğrencilerin Cinsiyete Göre Akademik Başarı

Durumlarıyla İlgili t-testi Sonuçları

\begin{tabular}{llrrrrc}
\hline Cinsiyet & $\mathrm{N}$ & Ortalama & \multicolumn{1}{c}{ ss } & sd & $\mathrm{T}$ & Anlamll1k \\
\hline Erkek & 276 & 2.55 & 0.45 & 290.268 & -4.364 & $.000^{*}$ \\
Kiz & 167 & 2.78 & 0.57 & & & \\
\hline & $* \mathrm{p}<.01$ & & & &
\end{tabular}

Öğrencilerin öğrenme stillerinin cinsiyete ve kayıtlı oldukları programa göre farklı olup olmadığını belirlemek için ki kare bağımsızlık testi kullanılmıştır. Öğrenme stilleri yerleştiren, değiştiren, ayrıştıran ve özümseyen olmak üzere dört farklı kategoride belirlenmiştir. Dört farklı kategoride belirlenen öğrenme stillerinin cinsiyete göre farklı olup olmadığını tespit etmek için ki kare testi yapılmış ve sonuçları Tablo 8'de gösterilmiştir. Tablo 8'deki sonuçlara göre öğrencilerin öğrenme stillerinin cinsiyete göre farklı olmadığ bulunmuştur $\left(\mathrm{x}^{2}: 3.805, \mathrm{p}>.05\right)$. Her iki cinsiyete göre yerleştiren, değiştiren, ayrıştıran ve özümseyen öğrenme stiline sahip olan öğrencilerin dağılım oranları benzerlik göstermektedir.

Tablo 8

Öğrencilerin Cinsiyete Göre Öğrenme Stillerine İlişkin

Ki-Kare Testi Sonuçları

\begin{tabular}{lccccr}
\hline \multirow{2}{*}{ Değişken } & Yerleştiren & Değiştiren & Ayrıştıran & Özümseyen & \\
\cline { 2 - 5 } & $\mathrm{f}(\%)$ & $\mathrm{f}(\%)$ & $\mathrm{f}(\%)$ & $\mathrm{f}(\%)$ & Toplam \\
\hline Erkek & $39(14.1)$ & $27(9.8)$ & $126(45.7)$ & $84(30.4)$ & 276 \\
K1z & $33(19.89)$ & $21(12.6)$ & $67(40.1)$ & $46(27.5)$ & 167 \\
Toplam & $72(16.3)$ & $48(10.8)$ & $193(43.6)$ & $130(29.3)$ & 443 \\
\hline
\end{tabular}

$\mathrm{x}^{2}: 3.805$, df: 3, p : .283, C: .092

Öğrencilerin kayıtlı olduğu öğretmen yetiştirme programına göre akademik başarı durumlarının değişip değişmediğini tespit etmek için tek yönlü ANOVA testi yapılmıştır. Öğrencilerin kayıtlı olduğu programa göre, dört tam puan üzerinden hesaplanan AGNO'larına ilişkin ortalama ve standart sapma değerleri Tablo 9'da verilmiştir. Öğrencilerin kayitlı olduğu öğretmen yetiştirme programına göre AGNO'ları arasında fark olup olmadığına ilişkin ANOVA sonuçları Tablo 10 'da gösterilmiştir. Öğrencilerin kayıtlı olduğu öğretmen yetiştirme programına göre AGNO'ları arasındaki farkın anlamlı olduğu bulunmuştur (F: 9.047, $\mathrm{p}<.01)$. 
Tablo 9

Öğrencilerin Kayıtlı Olduğu Programa Göre Akademik Başarı Durumları

\begin{tabular}{lrcc}
\hline & & & Standart \\
Öğrencinin Kayıtlı Olduğu Program & Ortalama & Sapma \\
\hline Sinıf Öğretmenliği (SÖ) & 174 & 2.76 & 0.35 \\
Beden Eğitimi ve Spor Öğretmenliği (BE) & 54 & 2.44 & 0.55 \\
Fen Bilgisi Öğretmenliği (FB) & 115 & 2.47 & 0.64 \\
İlköğretim Matematik Öğretmenliği (MÖ) & 40 & 2.77 & 0.40 \\
Türkçe Öğretmenliği (TÖ) & 60 & 2.71 & 0.53 \\
Toplam & 443 & 2.64 & 0.51 \\
\hline
\end{tabular}

LSD testi sonuçlarına göre, anlamlı farkın SÖ ile BE ve FB; BE ile MÖ; FB ile MÖ programına kayıtlı öğrenciler arasında olduğu bulunmuştur. AGNO ortalamalarının SÖ ile MÖ programına kayıtlı olan öğrenciler arasında en yüksek, BE ve FB programına kayıtlı öğrenciler arasında en düşük seviyede olduğu görülmektedir. TÖ programına kayıtlı öğrencilerin akademik başarı puan ortalamalarının genel ortalamaya daha yakın olduğu tespit edilmiştir.

Tablo 10

Öğrencilerin Kayıtlı Olduğu Öğretmen Yetiştirme Programına Göre

Akademik Başarı Durumuna İliş̧in ANOVA Testi Sonuçları

\begin{tabular}{|c|c|c|c|c|c|c|}
\hline $\begin{array}{l}\text { Varyansın } \\
\text { Kaynağı }\end{array}$ & $\begin{array}{l}\text { Kareler } \\
\text { toplamı }\end{array}$ & df & $\begin{array}{c}\text { Ortalama } \\
\text { kare }\end{array}$ & $\mathrm{F}$ & Anlamlilik & LSD \\
\hline Gruplararas1 & 9.032 & $\overline{4}$ & 2.258 & 9.047 & $.000^{*}$ & SÖ-BE, SÖ-FB, \\
\hline Gruplar içi & 109.309 & 438 & 0.250 & & & BE-MÖ, FB-MÖ \\
\hline Toplam & 118.341 & 442 & & & & \\
\hline
\end{tabular}

Öğrencilerin öğrenme stillerinin kayıtlı oldukları öğretmen yetiştirme programına göre anlamlı farklılık gösterip göstermediğine ilişkin ki kare testi sonuçları Tablo 11'de verilmiştir. Öğrenme stili ile kayıtlı olunan programın kategorik değişkenler olması sebebi ile ki kare bağımsızlık testi yapılmıştır. Öğrencilerin kayıtlı oldukları öğretmen yetiştirme programına göre öğrenme stillerinin farkl11ık gösterdiği bulunmuştur $\left(\mathrm{x}^{2}: 39,203, \mathrm{p}<.01\right)$. 
Tablo 11

Öğrencilerin Kayıtlı Olduğu Programa Göre Öğrenme Stillerine İlişkin

Ki-Kare Testi Sonuçları

\begin{tabular}{|c|c|c|c|c|c|}
\hline & Yerleştiren & Değiş̧tiren & Ayrıştıran & Özümseyen & \\
\hline Program & $f(\%)$ & $\mathrm{f}(\%)$ & $f(\%)$ & $\mathrm{f}(\%)$ & Toplam \\
\hline SÖ & $31(17.8)$ & $22(12.6)$ & $86(49.4)$ & $35(20.1)$ & $\overline{174}$ \\
\hline $\mathrm{BE}$ & $8(14.8)$ & $9(16.7)$ & $16(29.6)$ & $21(38.9)$ & 54 \\
\hline FB & $16(13.9)$ & $4(3.5)$ & 47 (40.9) & 48 (41.7) & 115 \\
\hline MÖ & $12(30.0)$ & $5(12.5)$ & $19(47.5)$ & $4(10.0)$ & 40 \\
\hline TÖ & $5(8.3)$ & $8(13.3)$ & $25(41.7)$ & $22(36.79)$ & 60 \\
\hline Toplam & $72(16.3)$ & $48(10.8)$ & 193 (43.6) & $130(29.3)$ & 443 \\
\hline
\end{tabular}

Öğrencilerin \% 16.3 'ü yerleştiren öğrenme stilini tercih etmektedir. Bu oran MÖ'de \% 30 ile en yüksek, TÖ'de ise $\% 8,3$ ile en düşük orandadır. Değiştiren öğrenme stiline sahip öğrencilerin oranı \% 10,8'dir. Bu oran BE öğrencilerinde \% 16.7 ile en yüksek, FB öğrencilerinde \% 3.5 ile en düşük düzeydedir. Öğrencilerin en fazla ayrıştıran öğrenme stiline sahip oldukları bulunmuştur (\% 43.6). Ancak bu oran SÖ (\% 49.4) ve MÖ (\% 47.5) öğrencilerinde daha yüksek düzeyde iken, BE öğrencilerinde (\% 29.6) daha düşük düzeydedir. Özümseyen öğrenme stiline sahip öğrencilerin oranı \% 29.3'tür. Özümseyen öğrenme stiline sahip öğrenciler FB (41.7), BE (\% $38.9)$ ve TÖ (\% 36.79) daha yüksek oranda iken SÖ (\% 20.1) ve MÖ (\% 10.0) öğrencileri arasında daha düşük düzeydedir.

\section{TARTIŞMA VE SONUÇ}

Yerleştiren, değiştiren, ayrıştıran ve özümseyen öğrenme stiline sahip öğrencilerin AGNO'ları arasındaki farkın anlamlı olmadığı bulunmuştur. Bu sonuçlar öğrenme stilleri ile ilgili olarak yapılan bazı çalışma sonuçları ile benzerlik gösterirken, diğer bazı çalışmalarda bulunan sonuçlardan farklıdır. Örneğin, Kılıç ve Karadeniz'in (2004) araştırmasında, öğrenme stilinin akademik başarı üzerinde anlamlı bir etki oluşturmadığı bulunmuştur. Diğer yandan Hasırc1 (2005), görsel öğrenme stillerine göre düzenlenen öğretimin görsel öğrenme stiline sahip öğrenciler için akademik başarı üzerinde etkili olduğunu bulmuştur. Lise öğrencilerinin tercih ettikleri öğrenme stillerinin biyoloji başarısına etkisinin incelendiği bir araştırmada (Özkan, Sungur ve Tekkaya 2004), öğrencilerin tercih ettikleri öğrenme stilleri ile biyoloji dersi başarıları arasında anlamlı fark bulunmuştur. Özümseyen öğrenme stiline sahip öğrencilerin ayrıştıran, değiştiren ve yerleştiren öğrenme stiline sahip 
öğrencilerden biyoloji dersinde daha başarılı olduğunu tespit edilmiştir. Farklı öğrenme stiline sahip öğrencilerin AGNO'larının farklı olmadığı ile ilgili bulunan sonuçlar, yapılan öğretim faaliyetlerinin belli bir öğrenme stiline sahip öğrenci grubunun başarılı olmasını destekleyecek şekilde olmadığını, öğretim etkinliklerinin farklı öğrenme stiline sahip öğrencileri benzer oranda desteklediği şeklinde yorumlanabilir. Diğer bir deyimle, öğrenme stili bu çalışma grubunda akademik başarıyı etkileyen bir değişken değildir.

Cinsiyete göre öğrencilerin akademik başarı durumlarının farklı olduğu bulunmuştur. Kız öğrencilerin akademik başarı ortalaması erkek öğrencilerin akademik başarı ortalamasından daha yüksektir. $\mathrm{Bu}$ sonuç, kızların akademik başarı durumunun erkeklerin akademik başarı durumlarından daha yüksek olduğunu gösteren bazı araştırma bulguları ile tutarlıdır (Bahar 2006; Koç, Avşaroğlu ve Sezer 2004; Büyüköztürk ve Denizkulu 2002; Duckworth ve Seligman 2006; Pomerantz, Altermatt ve Saxson 2002). Öğrencilerin akademik başarılarını etkileyen çok sayıda değişken vardır. Bunlar kısaca psikolojik, fiziksel ve toplumsal faktörler olarak gruplandırılabilir. Erkek ve kız öğrencilerin psikolojik özelliklerinin, sosyal ortamlarının ve barındıkları ortamın farklı olması, cinsiyet rollerinin oluşturduğu farklı beklentiler cinsiyete dayalı akademik başarı farkının oluşmasına sebep olabilir. Başarı farkının diğer sebeplerinden birisi de ilköğretim öğretmenliğinin daha çok kadın mesleği olarak algılanması ve buna dayalı olarak kız öğrencilerin öğretmenlik mesleğine karşı daha olumlu bir tutum geliştirmesi olabilir.

Öğrencilerin cinsiyete göre öğrenme stillerinin farklı olmadığ 1 bulunmuştur. İlgili literatürde benzer ve farklı sonuçlara rastlamak mümkündür. Örneğin, İngilizce öğretmen adaylarının kullandığı dil öğrenme stratejileri ile ilgili bir araştırmada (Dalkılıç 2004), dil öğrenme stratejilerinin kullanımı açısından bayan ve erkek öğrenciler arasında anlamlı bir fark olduğunu belirlemiştir. Bilgisayar ve öğretim teknolojileri eğitimi öğrencilerinin öğrenme biçemleri ve öğrenme tercihleri ile ilgili olarak yapılan araştırmada (Ateş ve Altun 2008), cinsiyete göre öğrencilerin öğrenme stillerinin değişmediği tespit edilmiştir. Öğretmen adaylarının düşünme stillerinin öğrenme biçimlerini tercih etmelerindeki etkisi ile ilgili olarak yapılan bir araştırmada (Çubukçu 2005), cinsiyetin öğrenme stilinde etkili olduğu bulunmuştur. Farklı tip öğrenme stil envanteri kullanan Uzuntiryaki, Bilgin ve Geban (2004), ilköğretim düzeyi öğretmen adaylarının öğrenme stilleri tercihleri ile cinsiyetleri arasındaki ilişkiyi inceledikleri araştırmada, cinsiyete göre öğrencilerin öğrenme stillerinin değişmediğini tespit etmişlerdir. Cinsiyete göre öğrencilerin öğrenme stilleri arasında fark bulunmaması, öğrencilerin öğrenme konusundaki tercih ve önceliklerinin cinsiyete göre değişmediğini göstermektedir. 
Öğrencilerin kayıtllı olduğu öğretmen yetiştirme programına göre AGNO'ları arasındaki fark anlamlı bulunmuştur. MÖ, SÖ ve TÖ programına kayıtlı öğrencilerin AGNO'larının BE ve FB programına kayıtlı öğrencilerin AGNO'larından daha yüksek olduğu tespit edilmiştir. Farklı öğretmen yetiştirme programlarına kayıtlı olan öğrencilerin akademik başarı durumlarının farklı olması doğal karşılanabilir. Çünkü hem bölüm programlarında yer alan ders ve etkinlikler, hem de bu dersleri yürüten ögretim elemanları farklıdır. Diğer yandan, farklı programlara kayıt yaptıran öğrencilerin giriş özellikleri de programdan programa farklılık göstermektedir.

Öğrencilerin kayıtlı oldukları öğretmen yetiştirme programına göre öğrenme stillerinin farklı olduğu bulunmuştur. Yerleştiren öğrenme stiline sahip öğrencilerin oranı MÖ programına kayıtlı öğrenciler arasında yüksek iken, TÖ programına kayıtlı öğrenciler arasında en düşük düzeydedir. Diğer dikkat çekici fark değiştiren öğrenme stiline sahip olan öğrencilerin oranı ile ilgilidir. BE programına kayıtlı öğrencilerde değiştiren öğrenme stiline sahip olma oranı en yüksek, FB programına kayıtlı öğrenciler arasında en düşük düzeydedir. Ayrıştıran öğrenme stiline sahip öğrencilerin oranı kayıtlı olunan öğretmen yetiştirme programına göre farkıdır. Örneğin bu oran, SÖ ve MÖ'de yüksek iken BE programına kayıtlı öğrenciler arasında daha düşük düzeydedir. Özümseyen öğrenme stiline sahip öğrenciler, FB, BE ve TÖ programına kayıtlı ögrenciler arasında daha yüksek oranda iken SÖ ve MÖ öğrencileri arasında daha düşük düzeydedir. Bu bulgular farklı bölüm ve branşlara kayıtlı öğrencilerin öğrenme stilleri arasındaki farkın anlamlı olduğuna ilişkin bazı araştırma bulguları (Oral 2003; Çubukçu 2005; Kaf Hasırc1 2006) ile tutarlıdır. Ayrıca, Kolb Ögrenme Stili'nin, bireylerin alanlarına (sosyal bilimler, fen bilimleri gibi) ve buna bağlı olarak mesleklerine göre öğrenme stillerinin farklı olabileceği öngörüsüyle örtüşmektedir (Aşkar ve Akkoyunlu, 1993). Farklı öğretmenlik branşlarının farklı etkinlik, yönelim ve tercihler gerektirdiği dikkate alınırsa, farklı branşlarda öğrenim gören öğrencilerin öğrenme stillerinin de farklı olması doğal karşılanabilir. Öte yandan, sınıf öğretmenliği programına kayıtlı öğrencilerin öğrenme stillerinin araştırıldığ bir çalışmada (Kaf Hasırcı 2006), sınıf öğretmenliği öğrencilerinin öğrenme stilleri ile ilgili bulunan oranlar mevcut çalışmada bulunan oranlardan kısmen farklıdır. Bu farklılık, aynı tür programa kayıtlı olsalar bile, her iki araştırmanın farklı zamanda, farklı ortamlarda ve farklı kişiler üzerinde yapılmış olmasından kaynaklanabilir. 
Çalışma grubundaki öğrencilerin öğrenme stilleri ile meslekleri arasındaki ilişki, önceki araştırma bulgularından biraz farklıdır. Örneğin Aşkar ve Akkoyunlu'nun (1993) çalışmasında matematik alanı değiştiren öğrenme stili ile ilişkilendirilmiştir. Mevcut çalışmada ise, matematik programına kayıtlı öğrencilerin en çok ayrıştıran öğrenme stiline sahip olduğu, değiştiren öğrenme stiline sahip öğrencilerin oranının ise oldukça düşük bir düzeyde olduğu bulunmuştur. Diğer yandan, sosyal ve fen bilimcilerin yaklaşık dörtte üçü özümseyen öğrenme stiline sahip iken; mevcut çalışmada alanı sosyal bilimler ve fen bilimleri olan öğrencilerden özümseyen öğrenme stiline sahip olanların oranı çok daha düşük bulunmuştur. $\mathrm{Bu}$ sonucun oluşmasında, öğrencilerin üniversite tercihlerini ilgi ve yetenekleri doğrultusunda yapmamış olmasının etkisi olabilir.

Bu sonuçlara dayalı olarak aşağıdaki önerilerde bulunulabilir:

1. $\mathrm{Bu}$ araştırma sonuçlarına göre, öğrencilerin baskın öğrenme stilleri kayıtlı olunan programa göre değişiklik gösterse bile yerleştiren, özümseyen, değiştiren ve ayrıştıran öğrenme stiline sahip öğrencilerin tüm programlarda bulunduğu belirlenmiştir. $\mathrm{Bu}$ nedenle, öğretim sürecinde öğretim elemanlarının her sınıfta farklı öğrenme stiline sahip öğrencilerin olduğunu düşünerek farklı tür öğrenme ortamları oluşturması, bu amaçla yöntem çeşitliliğine yer vermesi ve öğretim araç-gereçlerinden yararlanması öğrenme stili bakımından heterojen olan sınıflarda öğrenmeyi kolaylaştıracaktır.

2. Öğrencilerin çalışma alışkanlıklarının baskın öğrenme stillerine uygun olması öğrenci başarısını artırır. Öğrencilerin çalışma alışkanlıklarının baskın öğrenme stiline uygun olup olmadığı araştırılabilir. Ayrıca, öğrenciler bireysel çalışmalarını daha verimli yapabilmeleri ve baskın öğrenme stillerine uygun çalışma ortamları düzenlemeleri konusunda bilgilendirilebilir.

3. Çalışma grubundaki öğrencilerin kayıtlı oldukları programa göre baskın öğrenme stillerinin önceki bazı araştırma bulgularından farklı olma sebepleri araştırılabilir. 


\section{KAYNAKLAR}

Akkoyunlu, B. (1995). Bilgi Teknolojilerinin Okullarda Kullanımı ve Ögretmenlerin Rolü, Hacettepe Üniversitesi Ĕ̈itim Fakültesi Dergisi, 11, s.105-109.

Aşkar, P. ve Akkoyunlu, B. (1993). Kolb Öğrenme Stili Envanteri, Eğitim ve Bilim, 87, s.37-47.

Ateş, A. ve Altun, E. (2008). Learning Styles and Preferences For Students of Computer Education and Instructional Technologies, Eurasian Journal of Educational Research, 30, s. 1-16.

Babadoğan, C. (2000). Öğretim Sitili Odaklı Ders Tasarımı Geliştirme, Millî Eğitim Dergisi, 147, s.61-63.

Bahar, H. (2006). KPSS Puanlarının Akademik Başarı ve Cinsiyet Açısından Değerlendirilmesi, Eğitim ve Bilim, 31 (140), s. 68-74.

Büyüköztürk, Ş., Denizkulu, D. (2002). Bilgisayar ve öğretim teknolojileri öğretmenliği ile sınıf öğretmenliği programı öğrencilerinin akademik başarılarını etkileyen faktörler. Kuram ve Uygulamada Ĕ̆itim Yönetimi, 187-204.

Boydak, A. (2001). Öğrenme Stilleri, İstanbul: Beyaz Yayınları.

Mahiroğlu, A. (1999). Gazi Üniversitesi Teknik Eğitim Fakültesi Öğrencilerinin Öğrenme Stilleri, IV. Ulusal Eğitim Bilimleri Kongresi Bildiri Kitabl, Eskişehir: Anadolu Üniversitesi Basımevi.

Celkan, H. (1983). Öğrencilerin Akademik Başarılarında Zihin Dışındaki Faktörlerin Etkisi (Yayımlanmamış Doçentlik Tezi), Erzurum: Atatürk Üniversitesi Fen Edebiyat Fakültesi.

Dunn, R., Beudury, J., Klavas, A. (1989). Survey of Research on Learning Styles, Education Leadership, s. 50-57, (Çev. Cem Babadoğan, Eğitim Bilimleri Fakültesi Dergisi, 2001, 24 - 2, s.604-619).

Çubukçu, Z. (2005). Öğretmen Adaylarının Düşünme Stillerinin Öğrenme Biçimlerini Tercih Etmelerindeki Etkisi, Çağdaş Eğitim, 324, s. 22-31.

Dalkılıç, N. (2004). İngilizce Öğretmen Adayları Tarafından Kullanılan Dil Öğrenme Stratejileri, Elektronik Sosyal Bilimler Dergisi (www.esosder.com), 3 (10), s. 38-47.

Duckworth, A.L., Seligman, M.E. (2006). Self-discipline gives girls the edge: gender in self-discipline, grades, and achievement test scores. Journal of Educational Psychology, 98 (1), 198-208.

Ekici, G. (2003). Uzaktan Eğitim Ortamlarının Seçiminde Öğrencilerin Öğrenme Stillerinin Önemi, Hacettepe Üniversitesi Eğitim Fakültesi Dergisi, 24, s. 48-55. 
Kaf Hasırc1, Ö. (2005). Görsel Öğrenme Stillerine Göre Düzenlenen Öğretimin Akademik Başarı ve Kalıcılığa Etkisi, Ç. Ü. Sosyal Bilimler Enstitüsü Dergisi, 14 (2), s. 299-314.

Kaf Hasırc1, Ö. (2006), Sınıf Öğretmenliği Öğrencilerinin Öğrenme Stilleri: Çukurova Üniversitesi Örneği, Eğitimde Kuram ve Uygulama, 2 (1), s. $15-25$.

Kalaycı, Ş. (Ed.) (2006). SPSS Uygulamalı Çok Değişkenli İstatistik Teknikleri, Ankara: Asil Yayın Dağıtım.

Kılıç, E. (2002). Baskın Öğrenme Stilinin Öğrenme Etkinlikleri Tercihi ve Akademik Başarıya Etkisi, Ĕgitim Bilimleri ve Uygulama, 1 (1), s. 1-15.

Kılıç E. ve Karadeniz Ş. (2004). Cinsiyet ve Öğrenme Stilinin Gezinme Stratejisi ve Başarıya Etkisi Gazi Üniversitesi Gazi Eğitim Fakültesi Dergisi, 24 (3), s. 129-146.

Koç,M., Avşaroğlu, S., Sezer, A. (2004). Üniversite öğrencilerinin akademik başarıları ile problem alanları arasındaki ilişki, Selçuk Üniversitesi Sosyal Bilimler Dergisi, 11, 483-498.

Kolb, D. (1985). Learning Style Inventory: Self Scoring Inventory and Interpretation Booklet, Boston: Mc Ber and Company.

Küçükahmet, L. (1997). Ĕgitim Programlarl ve Öğretim-Öğretim Illke ve Yöntemleri, Ankara: Gazi Kitabevi.

Oral, B. (2003). Ortaöğretim Öğrencilerinin Öğrenme Stillerinin İncelenmesi, Kuram ve Uygulamada Eğitim Yönetimi, 35, s. 418-435.

Özgüven, İ. (1998). Bireyi Tanıma Teknikleri, Ankara: Pdrem Yayınları.

Pomerantz, E. M., Altermatt, E. R., Saxon, J. L. (2002). Making the grade but feeling distressed: gender differences in academic performance and internal distress. Journal of Educational Psychology, 94 (2), 396-404.

Özkan, Ş., Sungur, S. ve Tekkaya, C. (2004). Onuncu Sınıf Öğrencilerinin Tercih Ettikleri Öğrenme Stillerinin Biyoloji Başarılarına Etkisi, Eğitim ve Bilim, 29 (134), s. 75-79.

Uluğ, F. (1996). Okulda Başarı, İstanbul: Remzi Kitapevi.

Uzuntiryaki, E., Bilgin, İ. ve Geban, Ö. (2004). İlköğretim Düzeyi Öğretmen Adaylarının Öğrenme Stilleri Tercihleri ile Cinsiyetleri Arasındaki İlişkinin İncelenmesi, Hacettepe Üniversitesi Eğitim Fakültesi Dergisi, 26, s. $182-187$. 